\title{
Phylogenetic tree analysis for Bali Cattle based on partial sequence 16S rRNA Mitochondrial DNA
}

\author{
R. Misrianti ${ }^{1}, S . H$. Wijaya ${ }^{3}, C$. Sumantri ${ }^{2}, J$. Jakaria $^{2 *}$ \\ ${ }^{1}$ Graduate Program in Animal Production and Technology, Faculty of Animal Science \\ IPB University, JL Agatis, Dramaga Campus, Bogor 16680 - Indonesia \\ ${ }^{2}$ Department of Animal Production and Technology, Faculty of Animal Science \\ IPB University, JL Agatis, Dramaga Campus, Bogor 16680 - Indonesia \\ ${ }^{3}$ Department of Computer Science, Faculty of Mathematics and Natural Science \\ IPB University, JL Agatis, Dramaga Campus, Bogor 16680 - Indonesia
}

\begin{abstract}
Mitochondria DNA (mtDNA) as a source of genetic information based on the maternal genome, can provide important information for phylogenetic analysis and evolutionary biology. The objective of this study was to analyze the phylogenetic tree of Bali cattle with seven gene bank references (Bos indicus, Bos taurus, Bos frontalis, and Bos grunniens) based on partial sequence 16S rRNA mitochondria DNA. The Bayesian phylogenetic tree was constructed using BEAST 2.4. and visualization in Figtree 1.4.4 (tree.bio.ed.ac.uk/software/figtree/). The best model of evolution was carried out using jModelTest 2.1.7. The most optimal was the evolutionary models GTR + I + G with p-inv (I) 0,1990 and gamma shape 0.1960. The main result indicated that the Bali cattle were grouped into Bos javanicus. Phylogenetic analysis also successfully classifying Bos javanicus, Bos indicus, Bos taurus, Bos frontalis and Bos grunniens. These results will complete information about Bali cattle and useful for the preservation and conservation strategies of Indonesian animal genetic resources.
\end{abstract}

\section{Introduction}

Bali cattle as Indonesian native cattle have an important role in Indonesia. These cattle are very adaptive in tropical conditions and most suitable for sustainable small farming in Indonesia [1]. It's necessary to have information genetic of these cattle as basic information in a breeding program. Mitochondrial DNA (mtDNA) has been used in genetic studies because have a high mutation rate, absence of introns, and lack of recombinant event $[2,3$, 4]. The $16 \mathrm{~S}$ rRNA gene is a part of mtDNA has been reported as an advanced genetic marker for animal genetic diversity and phylogenetic studies. Yan et al. [5] reported 16S rRNA as a suitable marker for cattle phylogenetic analyses of Chinese cattle breeds. No

\footnotetext{
*Corresponding author: jakaria@apps.ipb.ac.id
} 
reports about 16S rRNA sequenced in Bali cattle. Most phylogenetic studies in Bali cattle using d-loop [6, 7], Cyt-b sequenced [8, 9], COI [10, 11]. Thus, the objective of this research was to identified a phylogenetic tree among Bali cattle and four cattle breeds (Bos indicus, Bos taurus, Bos frontalis, and Bos grunniens) based on partial sequenced of $16 \mathrm{~S}$ rRNA gene.

\section{Materials and methods}

\subsection{DNA materials}

The total of DNA samples was used in this study is twenty-two. The sourced of the sample from Nusa Penida Island-Bali. Furthermore, we also employed 16S rRNA sequence from GenBank, including Bos indicus Sahiwal (GeneBank Acc. KX575711), Bos indicus Wayanad (MF667931), Bos indicus breed Nellore (AY126697.1), Bos Frontalis (MW763078.1), Bos grunniens (MZ313873.1), and Bos taurus (GU947013.1).

\subsection{Primer, amplification, sequencing}

Primer design using primer 3 software based on Bos Indicus mitochondrial complete sequence (GenBank Accession No. AY126697) (http://primer3.ut.ee). Information about the sequenced and annealing temperature of the primer is shown in Table 1. The final volume of Polymerase Chain reaction (PCR) is $28 \mathrm{ul}$, containing $2 \mu \mathrm{L}$ DNA samples, 12,5 $\mu \mathrm{L}$ GoTaq ${ }^{\circledR}$ Green Master Mix (Promega, United States), $0,2 \mu \mathrm{L}$ of each Primer forward and reverse $(25 \mathrm{pmol} / \mu \mathrm{L})$, and $10.1 \mu \mathrm{L}$ nuclease-free water.

Table 1. Sequenced of Primer for Amplification Partial Sequence16S rRNA Gene

\begin{tabular}{|l|c|c|c|}
\hline Primer & Sequenced (5'-3')* & Length & Ta( $\left.{ }^{\mathbf{o}} \mathbf{C}\right)$ \\
\hline 16srRNA-1 & F:AAC AAA GCA TCC AGT TTA CAC C & $\begin{array}{c}846 \mathrm{pb} \\
(1038-1883 \mathrm{pb})\end{array}$ & 55 \\
\hline 16srRNA-1 & R: TTT CCT TAG ATG CAC TCC TGT G & \\
\hline
\end{tabular}

*GenBank access No. AY126697

PCR mix run using Applied Biosystems thermal cycler, with condition pre-denaturation was at $95^{\circ} \mathrm{C}$ for $5 \mathrm{~min}$, and amplification for 35 cycles (denaturation at $95^{\circ} \mathrm{C}$ for $10 \mathrm{~s}$, annealing at $57^{\circ} \mathrm{C}$ for $20 \mathrm{~s}$, extension at $72^{\circ} \mathrm{C}$ for $30 \mathrm{~s}$ ), and final elongation at $72^{\circ} \mathrm{C}$ for $5 \mathrm{~min}$. The PCR products were visualized by electrophoresis using $1.5 \%$ agarose gel and sequenced by 1st base-Selangor Malaysia (http://www.base-asia.com/fragment_analysis/).

\subsection{Data Analysis}

The sequenced of 16srRNA was analyzed using Sequences were analyzed using MEGA X 10.2.6 software. The Bayesian phylogenetic tree was constructed using BEAST 2.4. and visualization in Figtree 1.4.4 (tree.bio.ed.ac.uk/software/figtree/). The best model of evolution was carried out using jModelTest 2.1.7. The most optimal evolutionary models GTR + I + G with p-inv (I) 0,1990 and gamma shape 0.1960. 


\section{Results and Discussion}

The 16S rRNA gene of Bali cattle was successfully amplified with annealing temperature $55^{\circ} \mathrm{C}$. The primer amplified at position $1038 \mathrm{bp}$ to position $1883 \mathrm{bp}$ (according to GeneBank Acc number No. AY126697) with fragment prediction $846 \mathrm{bp}$. The frequency of A base was the highest (30.8) among three other bases ( $\mathrm{T}(23.90 \%)$; $\mathrm{C}(23.12 \%)$; $\mathrm{G}(19.18 \%))$. No significant differences in nucleotide composition of the mtDNA 16S rRNA gene were found among the Bali cattle. [5] reported the stable GC content in $16 \mathrm{~S}$ rRNA sequenced was helpful in phylogenetic analysis marker.

The nucleotide composition of A-T was higher than G-C. This result was conducted well with the previous study in Bali cattle, including d-loop sequenced [6, 7], Cyt-b sequenced [8,9], COI [10]. This finding is also consistent in another breed of cattle. [5] also identified the rich composition of $\mathrm{A}+\mathrm{T}$ in the $16 \mathrm{~S}$ rRNA gene of Chinese cattle.

Table 2. Nucleotide composition of Partial sequences 16S rRNA of Bali Cattle

\begin{tabular}{|c|c|c|c|c|c|c|c|}
\hline \multirow{2}{*}{ Sample } & \multicolumn{6}{|c|}{$\%$} & \multirow{2}{*}{ Total } \\
\hline & $\mathrm{T}(\mathrm{U})$ & $\mathrm{C}$ & $\mathrm{A}$ & $G$ & $\mathrm{~T}+\mathrm{A}$ & $\mathrm{C}+\mathrm{G}$ & \\
\hline B1 & 23.90 & 23.11 & 33.82 & 19.17 & 57.72 & 42.28 & 887 \\
\hline B2 & 23.90 & 23.11 & 33.82 & 19.17 & 57.72 & 42.28 & 887 \\
\hline B3 & 23.90 & 23.11 & 33.71 & 19.28 & 57.61 & 42.39 & 887 \\
\hline B4 & 23.90 & 23.11 & 33.82 & 19.17 & 57.72 & 42.28 & 887 \\
\hline B5 & 23.90 & 23.11 & 33.82 & 19.17 & 57.72 & 42.28 & 887 \\
\hline B6 & 23.90 & 23.11 & 33.82 & 19.17 & 57.72 & 42.28 & 887 \\
\hline B7 & 23.90 & 23.00 & 33.93 & 19.17 & 57.84 & 42.16 & 887 \\
\hline B8 & 23.90 & 23.34 & 33.60 & 19.17 & 57.50 & 42.50 & 887 \\
\hline B9 & 23.90 & 23.11 & 33.71 & 19.28 & 57.61 & 42.39 & 887 \\
\hline B10 & 23.90 & 23.11 & 33.71 & 19.28 & 57.61 & 42.39 & 887 \\
\hline B11 & 23.90 & 23.11 & 33.82 & 19.17 & 57.72 & 42.28 & 887 \\
\hline B12 & 23.90 & 23.11 & 33.82 & 19.17 & 57.72 & 42.28 & 887 \\
\hline B13 & 23.90 & 23.11 & 33.82 & 19.17 & 57.72 & 42.28 & 887 \\
\hline B14 & 23.90 & 23.11 & 33.82 & 19.17 & 57.72 & 42.28 & 887 \\
\hline B15 & 23.90 & 23.11 & 33.82 & 19.17 & 57.72 & 42.28 & 887 \\
\hline B16 & 23.90 & 23.11 & 33.82 & 19.17 & 57.72 & 42.28 & 887 \\
\hline B17 & 23.90 & 23.11 & 33.82 & 19.17 & 57.72 & 42.28 & 887 \\
\hline B18 & 23.90 & 23.11 & 33.82 & 19.17 & 57.72 & 42.28 & 887 \\
\hline B19 & 23.90 & 23.11 & 33.82 & 19.17 & 57.72 & 42.28 & 887 \\
\hline $\mathrm{B} 20$ & 23.90 & 23.11 & 33.82 & 19.17 & 57.72 & 42.28 & 887 \\
\hline B21 & 23.90 & 23.11 & 33.82 & 19.17 & 57.72 & 42.28 & 887 \\
\hline B22 & 23.90 & 23.11 & 33.82 & 19.17 & 57.72 & 42.28 & 887 \\
\hline Avg. & 23.90 & 23.12 & 33.80 & 19.18 & 57.77 & 42.23 & 887 \\
\hline
\end{tabular}

The phylogenetic tree showed Bali cattle were separated from other cattle breeds (Bos Frontalis, Bos grunniens, Bos indicus, and Bos taurus) based on partially sequenced $16 \mathrm{~S}$ rRNA gene (Figure 1). Hall (2001) identified the change of nucleotide sequence identified 
by the length of branch in the phylogenetic tree. [1] reported the Bali cattle are the domesticated direct descendant of the wild Banteng still surviving as an endangered species in three National Wild Reservation Parks (Ujung Kulon, Baluran, and Blambangan) in Java.

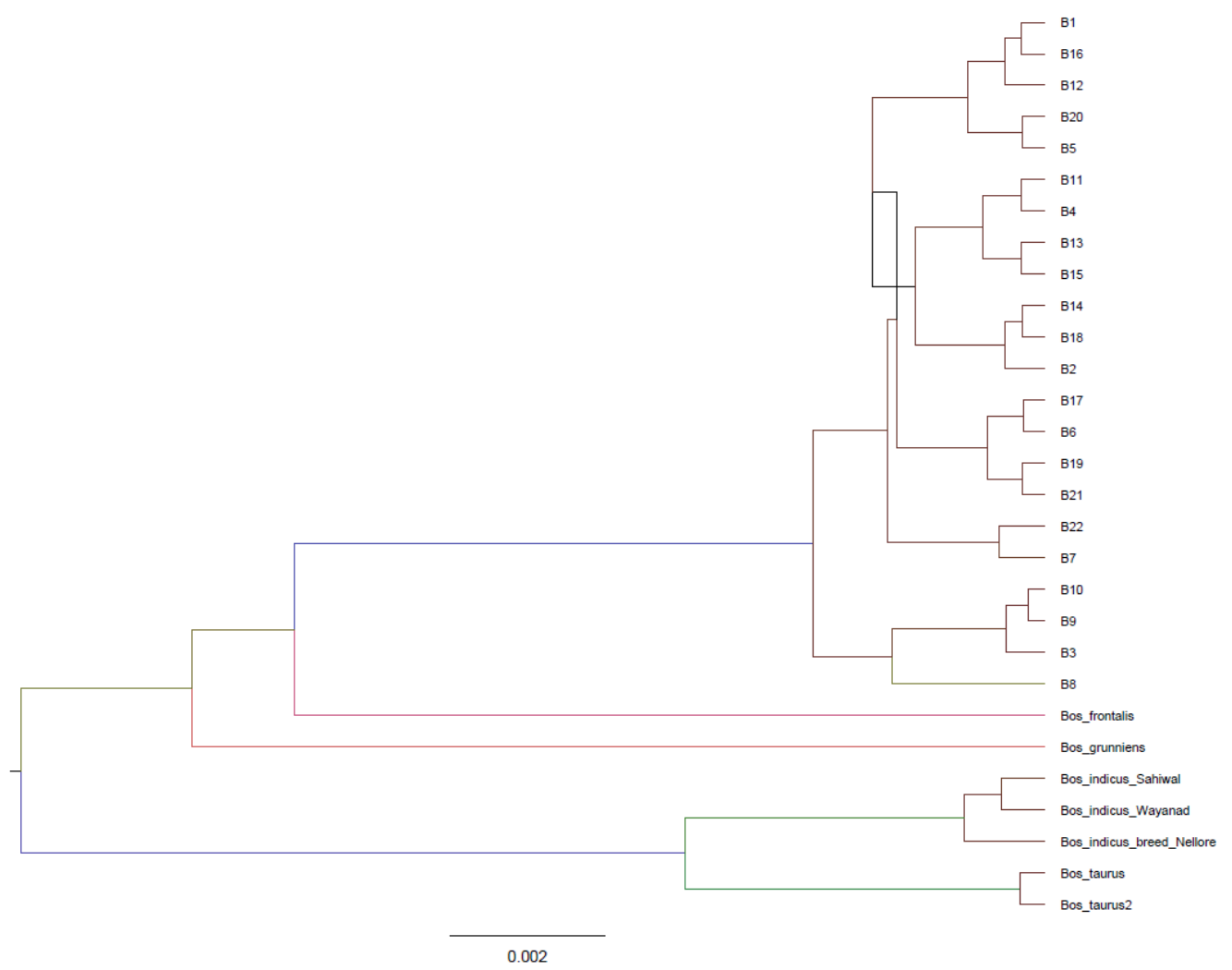

Fig. 1. The Bayesian Phylogenetic Tree of Bali Cattle and Other Cattle Breed Based on Partial Sequenced of 16S rRNA Gene (B: Bali cattle)

This result was consistent with a previous study, Jakaria et al (2019) identified Bali cattle as a different cluster with Bos taurus and Bos indicus based on the d-loop sequence. [12] also identified Bali cattle as a different group with Bos frontalis, Bos indicus, and Bison based on cyt-b sequenced.

\section{Conclusion}

The composition of the A-T base in the partially sequenced 16S rRNA gene was higher than C-G. The phylogenetic analysis using partial sequenced 16S rRNA gene indicated Bali cattle have a different cluster with Bos indicus, Bos taurus, Bos frontalis, and Bos grunniens.

This work was financially supported by the Directorate General of Resources for Science, Technology and Higher Education, Ministry of Research, Technology and Higher Education Fiscal Number: 2000/IT3.L1/PN/2021 date 15 March 2021. 


\section{References}

1. Martojo, Reprod Dom Anim, 47 (2012)

2. P. Di Lorenzo, H. Lancioni, S. Ceccobelli, L. Colli, I. Cardinali, T. Karsli, PLoS ONE, 13 (2018)

3. M. Rusdin, D. D Solihin, A. Gunawan, C. Talib, C. Sumantri, Tropical Animal Science Journal, 43 (2020)

4. C. Ginja, L. T. Gama, O. Cortés, Sci Rep, 10 (2020)

5. L. Yan, Y. She, M. A. Elzo, C. Zhang, XF, H. Chen, Arch. Anim. Breed, 62 (2019)

6. J. Jakaria, T. Musyaddad, S. Rahayu, M. Muladno, C. Sumantri, JITAA, 44 (2019)

7. Hikmawaty, Jakaria, A. Gunawan, M. I. A. Dagong, L. Rahim, IOP Conf. Ser.: Earth Environ. Sci, 492 (2020)

8. T. Hartatik, D. N. H. Hariyono, Y. Adinata, Biodiversitas, 20 (2019)

9. P.W. Prihandini, A. Primasari, M. Luthfi, J. Efendy, D. Pamungkas, JITV, 25 (2020)

10. N. N. W. Susari, P. Suastika, K. K. Agustina, Biodiversitas, 22 (2021)

11. A. Wulandari, V. M. A. Nurgiartiningsih, Kuswati, T. E. Susilorini, P. A. Partogi, IntlResearch J Advanced Engineering and Science, 4 (2019)

12. E. T. Margawati, S. D. Volkandari, Indriawati, M. Ridwan, JITV, 23(2018) 